\title{
Változások a pajzsmirigybetegségek radiojódkezelésében
}

\author{
Konrády András dr. \\ Jávorszky Ödön Kórház, Belgyógyászati Osztály és Izotóp Részleg, Vác
}

\begin{abstract}
A benignus és malignus pajzsmirigybetegségek radiojódkezelését körülbelül 70 éve vezették be, mindemellett a kezelés az indikáció, a dózis és az eljárás tekintetében a konszenzus hiányával jellemezhető. Az összefoglaló foglalkozik az immunogén hyperthyreosis kezelésének eredményeivel, beleértve az endokrin orbitopathia problémáját. Tárgyalja a toxikus és nem toxikus multinodularis strúma radiojódkezelését, hangsúlyozva a jódfelvétel növelésének jelentőségét. Ebben a vonatkozásban a rekombináns humán tireotropin alkalmazását szükséges említeni. A pajzsmirigyrák kezelési protokollja is változott, a kis kockázatú betegeken a kezelés ineffektív, szükségtelen. Több figyelmet érdemel a radiojód carcinogen hatása. Számos említett probléma jól megtervezett, prospektív tanulmányokat igényel, hogy az alapvető problémák tisztázódjanak. A szerző hangsúlyozza: a radiojódterápia megválasztásánál a még megfelelően hatékony, legalacsonyabb dózisra kell törekedni. Orv. Hetil., 2016, 157(3), 83-88.
\end{abstract}

Kulcsszavak: jóindulatú pajzsmirigybetegségek, pajzsmirigyrák, radiojódterápia változásai

\section{Changes in radioiodine therapy for thyroid disorders}

Radioiodine therapy for benign and malignant thyroid diseases was introduced about 70 years ago, however, there is still a lack of consensus regarding indications, doses and procedure. This review covers treatment results in immunogenic hyperthyroidism including the problem of orbitopathy. Radioiodine therapy for toxic and non-toxic multinodular goiter is also discussed with striking possibility of enhanching the radioiodine uptake. In this respect the recombinant human thyrotropin should be mentioned. Thyroid cancer treatment protocol has changed, too, due to ineffectivity in low-risk patients. More attention is needed to the carcinogenecity of radioiodine. The numerous problems mentioned above require large and well-designed prospective trials to resolve the fundamental questions. The author emphasizes that radioiodine dose should be administered in doses as low as reasonably achievable.

Keywords: benign thyroid diseases, thyroid cancer, changes of radioiodine therapy

Konrády, A. [Changes in radioiodine therapy for thyroid disorders]. Orv. Hetil., 2016, 157(3), 83-88.

(Beérkezett: 2015. október 6.; elfogadva: 2015. november 5.)

\section{Rövidítések}

aTPO = peroxidáz elleni antitest; BG-kór $=$ Basedow-Gravesbetegség; DTC = differenciált pajzsmirigyrák; EOP = endokrin orbitopathia; hTG = humán tireoglobulin; NIS = nátrium-jodid-szimporter; rhTSH = rekombináns humán tireotropin; $\mathrm{TRAb}=$ tireotropinreceptor-antitest

A pajzsmirigybetegségek jódizotópos kezelésének története csaknem háromnegyed százados, 1942-ben kezdődött [1]. Először a jód 130-as izotópját alkalmazták, majd uralkodóvá vált a béta- és gamma-sugárzó 131-es izotóp ( $\left.{ }^{131} \mathrm{I}\right)$. A múlt század '70-es éveiben kísérletek történtek a ${ }^{125}$ I alkalmazásával is, amelynek kedvező fizikai tulajdonságai alapján jó eredményeket vártunk, de a klinikai gyakorlat a várakozásokat nem igazolta. Ma már csak a jód 131-es izotópját használjuk.

Évtizedek során e terápiás módszer jelentős változásokon ment keresztül. Először csak hyperthyreosisban alkalmazták, majd a pajzsmirigyrák kezelésében, az utóbbi két évtizedben pedig euthyreosisos strúmák megkisebbítésére is. Kezdettől vitás az indikációk és az optimális dózis meghatározása. 
Az utóbbi 1-2 évtizedben egyre nagyobb figyelmet kapott a jódizotópterápia rövid és hosszú távú mellékhatásainak feltárása, ami visszahatott az alkalmazásra is. Jelentős lépés volt a pajzsmirigy jódfelvételének fokozása rekombináns humán tireotropin adásával. Ez lehetővé tette az alkalmazott dózisok csökkentését is. A következőkben a pajzsmirigybetegségek jódizotópos kezelésének ellentmondásaira, illetve változásaira szeretnénk felhívni a figyelmet, a teljesség igénye nélkül.

\section{A hyperthyreosis radiojódkezelése}

\section{Immunhyperthyreosis}

Évente milliókat kezelnek Basedow-Graves-kór (BGkór) miatt ${ }^{131} \mathrm{I}$-dal, a hazai terápiák száma is évente több ezer. Országonként és régiónként változó a kezelés gyakorlata, és ma is hiányzik az egyetértés az indikáció, a dózisok és a gondozás tekintetében. Az alkalmazást befolyásolják a helyi lehetőségek és szokások, sőt egyes országokban az egészségügyi biztosítási feltételek is.

Tényként fogadható el, hogy az immunhyperthyreosisos betegek 50-90\%-a végül meggyógyul, és a terápiát követő hypothyreosis gyakorlatilag elkerülhetetlen: az első évben 5-50\%, amely évente 3-5\%-kal emelkedik [2].

Az indikáció tekintetében viszonylag nagy az egyetértés abban, hogy a gátlószerre nem gyógyuló vagy intoleranciás esetekben definitív terápia végzendő: mütét vagy izotópkezelés. A választást befolyásolja a strúma nagysága, exophthalmus jelenléte, mútéti teherbíró képesség stb. A dózis számítása vitatottabb. Alkalmaznak fix dózisokat, mások szofisztikált számításokkal határozzák meg a beadandó mennyiséget - az elért eredmények lényeges különbséget nem mutatnak. A késői jódfelvételi adatok mérése pontosabb, kisebb dózis beadását teszi lehetővé [3]. Az „ablatív” koncepció alkalmazói lényegesen nagyobb adagokat használnak, akár 96\%-os sikerrel, és természetesen nagy posztterápiás hypothyreosis-előfordulással [4]. A módszer optimalizálása folyamatos, bár az egyéni sugárérzékenység modellezése, kiszámítása utópia. Az euthyreosisra törekvők 70-150 Gy, az ablatív kezelést alkalmazók 200-300 Gy irradiációs dózist ajánlanak.

Érdeklődés mutatkozik a radiojódkezelést követő immunológiai történések területén. Izotópkezelés hatására a folliculus sejtkárosodás miatt antigén-kiáramlás következik be. A TSH-receptor ectodomainje könnyen leválik és antigénként viselkedik [5]. A keletkezett TSH-receptor-antitestek (TRAb) szintje 3-6 hónapig emelkedik, majd csökken. Mütét vagy thyreostaticus kezelés után 70-80\%-ban eltûnik, radiojódkezelés után marad a legtovább emelkedett [6]. Átmeneti emelkedés észlelhető a proinflammátoros és antiinflammátoros citokineknél, a legtovább az IFN-gamma-termelés nő (váltás az l-es típusú citokinprofil felé) [7]. A celluláris immunválaszt a B-sejt-aktivitás növekedése jelzi, nő az immunglobulintermelés, s ezt a szuppresszor T-sejtek számának csökke- nésével lehet összefüggésbe hozni. E változások föként azokon a betegeken észlelhetők, akik hypothyreosisosakká váltak [8].

Több probléma tisztázódott a preterápiás metimazolkezeléssel kapcsolatban: 14 tanulmány összesítése alapján állítható, hogy ez a sikertelen izotópkezelések számát növeli, és a terápia utáni hypothyreosisok valószínúségét csökkenti [9], bár ez nem egyértelmúen elfogadott. Megváltoztatja a jódkinetikát, a radioszenzitivitást, szabadgyök-fogó. A kezelés előtt 2 nappal javasolják kihagyni a metimazolt, így nőhet a jódfelvétel, valamint a ${ }^{131}$ I effektív felezési ideje, vagyis a dózis csökkenthető [10]. 7 nap múlva visszaállítva a metimazolkezelést, a terápia hatásfoka nem csökken.

Ezek az autoimmun válaszok csak a megfelelő módszerek kifejlesztése után váltak ismertté. Jelentőségük részben diagnosztikus (mikor és mit vegyünk figyelembe?), részben a kezelést követő hipofunkció tekintetében figyelemre méltóak.

\section{Izotópkezelés és endokrin orbitopathia}

Sokszor idézett tény, hogy radiojódkezelést követően endokrin orbitopathia (EOP) alakulhat ki vagy a meglévő rosszabbodik [11]. Ez összefüggésben van a TRAb emelkedett szintjével. Az antithyreoid terápiák között ${ }^{131}$ I-kezeléskor észlelhető leggyakrabban: de novo keletkező EOP (akár 20\%-ban) vagy a meglevő romlása 5-7\%ban [12]. A jelenség sokszor átmeneti, és a szteroid jó hatású [11]. Magas TRAb-szint, domináló trijód-tironin- (T3-) szaporulat és korai hypothyreosis kialakulása fokozzák a rizikót. Említendő a dohányzás káros szerepe is $[13,14]$. Mivel a hypothyreosis egyértelmúen rontja a helyzetet, korai szubsztitúció szükséges.

Az EOP-tól való félelem szigorította a BG-betegeken a radiojódkezelés indikációját, másrészt sok helyen minimális szemtünet észlelésekor is már szteroidot adnak.

Az EOP kezelésekor a pajzsmirigy mútéti vagy irradiációs ablatióját mérlegelik [15], nyilvánvalóan az antigénforrás eliminálására. Amíg tehát az EOP kialakulásáról, illetve rosszabbodásáról értekezhetünk radiojódkezelés után, radiojódablatiót ajánlanak az EOP kezelésére [16], s ezzel a módszerrel jó eredményeket értek el. Érdekesség, hogy a mútéti ablatio mellett statinok alkalmazásával redukálható az EOP kialakulásának veszélye [17].

\section{Göbös strúmák radiojódkezelése}

A toxikus egy- vagy többgöbös strúmák esetében a BGkórnál sokkal kedvezőbb az arány a gyógyult esetek és a hypothyreosis elöfordulása tekintetében. A gyógyulás akár $90 \%$ feletti lehet, hypothyreosis $10 \%$ körüli és fóként akkor fordul elö, ha az extranodularis szövet szuppreszsziója nem volt megfelelő. A szembeötlő változás az euthyreosisos multinodularis, kompresszív strúmák izotópkezelésével következett be, amikor is a célt nem a funkció, 
hanem a térfogat csökkentésében jelölték meg [18]. A volumenredukció egyéves kontrollnál 40\%, 2-5 éves ellenőrzéskor $50-60 \%$ is lehet $[19,20]$, és a kompressziós tünetek szintén mérséklődnek [21]. A módszert ma már a terápiás útmutatók is ajánlják [22]. Természetesen fenn kell tartani ezekben az esetekben a mútét prioritását, de idős betegen vagy komorbiditás esetén a mütét nem mindig végezhető el. Az eljárás előnye, hogy ismételhető, költség-hatékonyság aránya kedvező és sok helyen ambulanter is elvégezhető.

Az ajánlott dózis toxikus adenomák esetén 300-400 Gy, többgöbös strúmákban 150 Gy (utóbbiaknál az autonóm térfogatot az egész volumen 50\%-ában jelölik meg) [23]. A mikrodozimetria sok nehézséget jelent, ugyanis a kisebb vagy nagyobb folliculusokban az elnyelt dózis akár 30\%-ban különbözhet BG-kórban [24], és ez még fokozottabban jelenik meg multinodularis strúmákban. A becsült, fix dózissal kezelt betegek eredményei lényegesen nem különböznek az individuálisan számított dózissal kezeltekétől [25], a számításos módszert mégsem kellene mellőzni [26]. A funkcionális, autonóm térfogat kiszámítására a német iskola ajánlott tetszetős módszereket $[27,28]$, ezek széles körben nem terjedtek el, mert az elért eredmények így sem lettek jobbak [29].

$\mathrm{Az}$ euthyreosisos vagy szubklinikus hyperthyreosissal járó multinodularis strúmák kezelésében a legfőbb akadály a rendszerint alacsony jódfelvétel, ezzel összefüggésben nagy izotópdózisokra van szükség. Mivel azonban nagyobb jódfelvétel esetén kevesebb izotópot kell beadni, különös jelentőséggel bírnak azok a módszerek, amelyekkel a jódfelvételt növelni lehet. Ez az egyik módja, hogy érvényt szerezzünk az izotópterápia alapelvének, az úgynevezett ALARA-elvnek (as low as reasonably achievable): a lehető legkisebb legyen a beteg izotópterhelése, amellyel észszerűen keresztülvihető és eredményes lesz a kezelése, a gazdasági és szociális tényezők figyelembevételével. A radiojódfelvétel növelését célozza a jódszegény diéta. Ennél hatékonyabb a jódürítést fokozó furosemid alkalmazása, bár ilyenkor a jódclearance is csökken és ez a teljestest-besugárzást növeli [26]. A lítiumsók a pajzsmirigyhormon-inkréció gátlásával hatnak, a jódfelvételt szignifikánsan nem növelik.

Áttörést jelentett az utóbbi években a rekombináns humán tireotropin (rhTSH) alkalmazása: igen hatékonyan növeli a jódfelvételt és más kedvező hatásai is vannak [30]. Megváltoztatja a mikrodozimetriát, a kevésbé aktív, „dormant” folliculus sejtek aktívabbá válnak, homogénebbé válik a jódfelvétel. Fokozza a mirigy radioszenzitivitását. 100 Gy besugárzási dózissal végzett terápia eredménye azonos volt azzal, ha 50 Gy-t adtak rhTSH-előkészítéssel [31]. Előnyösen változik a jódkinetika, emiatt az extrathyreoidealis sugárterhelés csökken. A fentiek eredményeképpen a pajzsmirigyvolumen nagyobb mértékben csökken, mint a konvencionális terápiánál [30]. Utóbbinál a strúma nagysága és a volumencsökkenés fordított korrelációt mutat, rhTSH-val ez megfordul: minél nagyobb a volumen, annál kedvezőbb a terápiás hatás, a volumencsökkenés. Érthetően a kompressziós tünetek is csökkennek. Az rhTSH alkalmazása ilyen esetekben „off-label”, külön engedélyhez kötött. Megjegyzendő, hogy míg pajzsmirigyrák remnant ablatiójakor $2 \times 0,9 \mathrm{mg}$ rhTSH-t adunk, itt $0,1-0,3 \mathrm{mg}$ is elegendő.

Újabban a jódfelvétel növelésére toxikus multinodularis strúmás betegeken 6 hétig tartó metimazolkezelést javasoltak (30 mg/nap), amely csaknem megduplázta a felvételt ( $32 \%$ vs. $63 \%)$, ezzel az izotópdózis harmadával csökkenthető volt [32]. Az egyéves kontroll a terápiás hatékonyság növekedését mutatta. Nehéz magyarázni ezeket a még megerösítésre szoruló eredményeket. A jódfelvétel növekedése valószínúleg a metimazol jóddepléciós hatásával hozható összefüggésbe. Egyébként a magas jódfelvétel a metabolikus aktivitást tükrözheti, az pedig fokozott antioxidatív védelemmel jár, és így a sugárérzékenység csökkenhet. Ezt az idézett tanulmányban nem észlelték. Érdeklődéssel várjuk az utánvizsgálatok eredményeit.

1984-ben e hasábokon közöltünk egy esetet, akinél a toxikus adenoma mütétét követően 3 hónap múlva exophthalmussal kísért hyperthyreosis (BG-kór) alakult ki [33]. A stimuláló antitest jelenlétét bár az akkori módszerrel (túlélő pajzsmirigyszeleteken cAMP-serkentés) nem tudtuk kimutatni, de feltételeztük. A '90-es években kazuisztikus közléseket követően már nagyobb betegszám megfigyelése alapján leírták, hogy multinodularis strúmák radiojódkezelését követően immunhyperthyreosis alakult ki $[34,35]$. Ennek gyakorisága 1-5\%. 174 multinodularis strúma radiojódkezelése után magunk két esetet észleltünk (1,15\%). A különbségek összefüggésben állhatnak a jódellátottsággal. Euthyreosisos multinodularis golyvák izotópkezelésekor, illetve a nyomon követés folyamán fentieket figyelembe kell venni (TRAb, aTPO ellenőrzése).

\section{A differenciált pajzsmirigyrák kezelése}

A mütétet követő radiojódterápia céljai: remnant ablatio (a normális residualis szövet destrukciója), adjuváns terápia (a neoplasztikus gócok elpusztítása, illetve a posztterápiás scan és a hTg-szint nyomon követésének megkönnyítése). Kis rizikó esetén nem volt a kezelésnek számottevő hatása [36], sőt az izotópkezelteken több volt a recidíva, mint a nem kezelteken [37]. E betegcsoport hosszú távú prognózisa jó, érthető ezért, hogy az utóbbi években a kis rizikójú betegek kezelését nem ajánlják, kivételt képeznek azok az esetek, ahol agresszív, invazív a tumor vagy BRAF-pozitivitás áll fenn [38]. $\mathrm{Az}$ intermedier csoportban (minimális terjedés a kötőszövetbe, nyirokcsomóáttét, agresszív hisztológia) is javultak a túlélési mutatók [39]. Mára tehát egyértelmúvé vált, hogy a differenciált pajzsmirigyrák izotópkezelése a kis rizikójú csoportban általában nem indokolt (hangsúlyozandó ez azért is, mert a kezelések száma világszerte növekszik), de folyamatban vannak olyan vizsgálatok, 
amelyekben összehasonlítják az izotóppal kezeltek eredményeit a nem kezeltekével (Iodine or Not - IoN).

Az ablatív dózis kérdése vitatott. Kezdetben 100 mCi-t adtak, a későbbi ajánlás már 30-100 mCi közötti dózist javasol az ablatióra [36]. Prospektív, randomizált tanulmányok nem találtak különbséget a 30 és $100 \mathrm{mCi}$ között az ablatiós siker tekintetében [36], illetve a $30 \mathrm{mCi}$ ${ }^{131}$ I rhTSH-előkészítéssel is hatékony volt [40]. Nagy remnant esetén nagyobb dózis szükséges. A hosszú távú, összehasonlító vizsgálatok a kis és nagy dózisok tekintetében ellentmondó eredményeket mutattak, és némi visszatérés is látszik a $100 \mathrm{mCi}$ dózis felé (amit minél hamarabb kellene alkalmazni), fóleg azokban az esetekben, amikor a mútét inkomplett volt [41]. Nodalis érintettség esetén, tekintet nélkül a primer tumor nagyságára, 100-175 mCi adását ajánlják [42]. Az észak-amerikai gyakorlat szigorúbb az európainál (jelenleg).

A kezeléshez magas TSH kell $(>30 \mathrm{mU} / \mathrm{l})$, ezt hormonmegvonással vagy rhTSH-val lehet elérni. Utóbbinak számos előnye van: a beteg nem lesz hypothyreosisos a kezelés előtt, úgy változik meg a jódkinetika, hogy az extrathyreoidealis sugárterhelés lényegesen csökken stb. Ma már egyértelmüen indokolt az rhTSH alkalmazása ablatio előtt (jóváhagyott eljárás).

A perzisztáló-recidiváló esetekben 100-200 mCi szükséges. Ezt is lehet rhTSH-előkészítéssel eredményesen elvégezni, de az eljárás egyelőre „off-label” (engedélyhez kötött). A hTG-pozitív, radiojódscan-negatív (TENIS-szindróma) betegeken korábban empirikus terápia jött szóba 100-200 mCi-vel [36] és a posztterápiás scan deríthette ki a hTG-emelkedés strukturális hátterét. $\mathrm{Az}$ empirikus terápiával sokan nem értenek egyet. Ezekben az esetekben nincs „betegségmentesség”, s a továbbiakat PET-CT döntheti el: pozitivitása esetén jódrezisztencia áll fenn [43].

Időszerűvé vált megfogalmazni a jódrezisztencia eseteit: idetartozik, hogy legalább egy laesio nem vesz fel jódot, izotópkezelés után egy éven belül progresszió észlelhető, a kumulatív dózis meghaladta a $600 \mathrm{mCi}-\mathrm{t}, \mathrm{az}$ előrehaladt betegségben thyreoidectomia nem lehetséges (ugyanis a radiojód ineffektív, ha a pajzsmirigyet nem távolították el, és így a radiojódfelvétel nem vizsgálható) [44]. A rezisztencia jelentősége, hogy ilyenkor egyéb terápiás eljárásokat kell igénybe venni (multikinázgátlók, külső besugárzás stb.).

\section{A radiojódterápia késői mellékhatásai}

Az izotópkezelés korai mellékhatása lehet a mirigy átmeneti megduzzadása, sialadenitis (amely később szájszárazsághoz vezethet). Ezek előfordulása, kezelése és jelentősége jól definiált [26]. A későbbi mellékhatások több figyelmet igényelnek.

A múlt század '90-es éveiben jelentek meg nagyszámú beteg megfigyelésén alapuló tanulmányok, amelyek az izotópkezelés késői, daganatkeltő hatását vizsgálták (második primer malignoma - SPM). Megállapították, hogy a hyperthyreosis radiojódkezelését követően ilyen veszélytől nem kell tartani [45]. A pajzsmirigyrákok jódizotópos kezelésekor azonban sokkal nagyobb dózisokra van szükség, mint hyperthyreosisban (akár 10-szer nagyobb adagokról van szó), ezeknél az SPM előfordulásának veszélye nem hanyagolható el és mindenképpen nagyobb, mint a radiojóddal nem kezelteken [46]. Svéd, olasz és francia területről gyújtött betegadatokban 6841 pajzsmirigyrákos ${ }^{131} \mathrm{I}$-dal kezelt betegről van szó. Látható, hogy SPM 576 betegen $(8,4 \%)$ jelentkezett, átlagosan 15 év után, és harmadik tumor jelentkezése sem volt ritka [47]. Leggyakoribb volt a colorectalis, csont- és kötőszöveti, valamint a nyálmirigyrák, de nőtt a leukaemiák száma is, mégpedig korrelációban az alkalmazott dózissal. 3,7 GBq dózis felett már erős asszociáció észlelhető leukaemiák esetében [48].

Az SPM előfordulása a kumulatív dózissal mutat öszszefüggést. A mellrák tekintetében a gyakoribb előfordulást nem a ${ }^{131}$ I-expozícióval magyarázták (az emlőmirigy sejtjei ugyan NIS-t expresszálnak, de radiojódkezelés után a mell nem vizualizálható), ennek ellenére a fokozott rizikó kimutatható [49]. Mivel a gyomor, a nyálmirigyek és a hólyag kapja a legnagyobb besugárzási dózist, igen fontos a kezelés utáni ápolási protokoll (bő folyadék, szekretagógok alkalmazása, hashajtás stb.).

3,7 GBq (100 mCi) alkalmazásakor 53-mal több szolid tumor és 3-mal több leukaemia várható 10 éven belül 10000 betegen [44]. Ez nem kontraindikálja ugyan a ${ }^{131}$ I-terápiát azokon a betegeken, akiken eredmény várható, de hangsúlyosan kell tekintetbe venni a nagy dózisok alkalmazásánál és ismételt kezeléseknél. Mindezt az ALARA-elv rögzíti (1. fentebb!).

Összességében megállapítható, hogy a benignus pajzsmirigybetegek radiojódkezelésekor szignifikáns onkogén hatással nem kell számolni! Pajzsmirigyrákban a nagy dózisú és ismételt terápiáknál azonban (különösen 20$30 \mathrm{GBq}$ feletti kumulatív dózisoknál) gondolni kell a veszélyeztetettségre. Ezek az esetek számszerúen az összes radiojódkezelés csak kis töredékét képezik.

Legújabban 4000 hyperthyreosisos és 1022 euthyreosisos strúmás betegen végzett radiojódterápiát követően, átlag 11,5 éves megfigyelés alapján a cerebrovascularis morbiditás növekedéséről számolnak be [50]. Ezt az atherosclerosis indukálásával vagy felgyorsításával magyarázzák és az izotóp lokális, a carotisrendszerre kifejtett besugárzásával hozzák összefüggésbe. Az egyébként meglepő adatok megerősítést igényelnek.

\section{Következtetések}

Megállapítható, hogy a pajzsmirigybetegségek radiojódkezelése biztonságos és hatékony eljárás. Az indikációk körvonalazódnak, a dózisok tekintetében még nagy a véleményeltérés. Gyógyszer-intolerancia vagy inoperabilitás esetén az eljárás nélkülözhetetlen. Tisztázódott a radiojód szerepe BG-kórban és autonóm múködésű göbös strúmákban. Lehetőség nyílt a pajzsmirigyvolumen 
megkisebbítésére is (radioreszekció). Javultak a pajzsmirigyrákos betegek gyógyulási esélyei is. Mindazonáltal érdemes ismerni a ${ }^{131}$ I-kezelés káros hatásait is (EOP keletkezése BG-kórban, onkogén hatások pajzsmirigyrák kezelésekor stb.) ahhoz, hogy megalapozottan és megfontoltan döntsünk az izotóp beadásáról. Ehhez segítenek az utóbbi időben feltárt ellentmondások, tények és eredmények.

Megjegyzés: A kézirat beküldése után jelent meg az Amerikai Pajzsmirigy Társaság (American Thytoid Associatiohn - ATA) 2015. évi átfogó, részletes irányelve, amely a 2009. kiadáshoz képest változásokat tartalmaz a radiojódterápiák alkalmazásáról (Running title: ATA Thyroid Nodule/DTC Guidelines, Thyroid, DOI: 101089 /thy 2015.0020). Ugyancsak ez idő tájt jelent meg a Thyroid tumors címú monográfia 4. kiadása ( $M$. Schlumberger, F. Pacini, M. Tuttle, Nucleon), a szerzőhármas európai-amerikai egyeztetésre utal.

Jelen összefoglalónk fóbb megállapításai összhangban vannak e két munkával.

Anyagi támogatás: A közlemény megírása anyagi támogatásban nem részesült.

A cikk végleges változatát a szerző olvasta és jóváhagyta. Érdekeltségek: A szerző a Sanofi-Aventis tanácsadója.

\section{Irodalom}

[1] Becker, D. V., Sawin, C. T.: Radioiodine and thyroid disease: the beginning. Semin. Nucl. Med., 1996, 26(3), 155-164.

[2] Nygaard, B., Hegedüs, L., Gervil, M., et al.: Influence of compensated radioiodine therapy on thyroid volume and incidence of hypothyroidism in Graves' disease. J. Intern. Med., 1995, 238(6), 491-497.

[3] Bajnok, L., Mezósi, E., Nagy, E., et al.: Calculation of the radioiodine dose for the treatment of Graves' hyperthyroidism: is more than seven-thousand rad target dose necessary? Thyroid, 1999 $9(9), 865-869$

[4] Kobe, C., Eschner, W., Sudbrock, F., et al.: Graves' disease and radioiodine therapy: is success of ablation dependent on the achieved dose above 200 Gy? Nuklearmedizin, 2008, 47(1), 13-17.

[5] Davies, T. F., Ando, T., Lin, R. Y., et al.: Thyrotropin receptorassociated diseases: from adenomata to Graves disease. J. Clin. Invest., 2005, 115(8), 1972-1983.

[6] Laurberg, P., Wallin, G., Tallstedt, L., et al.: TSH-receptor autoimmunity in Graves' disease after therapy with anti-thyroid drugs, surgery, or radioiodine: a 5 -year prospective randomized study. Eur. J. Endocrinol., 2008, 158(1), 69-75.

[7] Jones, B. M., Kwok, C. C., Kung, A., W.: Effect of radioactive iodine therapy on cytokine production in Graves' disease: transient increases in interleukin-4 (IL-4), IL-6, IL-10, and tumor necrosis factor-alpha, with longer term increases in interferon-gamma production. J. Clin. Endocr. Metab., 1999, 84(11), 4106-4110.

[8] Wilson, R., McKillop, J. H., Jenkins, C., et al.: In vivo and in vitro studies into the immunological changes following iodine 131 therapy for Graves' disease. Eur. J. Nucl. Med., 1991, 18(4), 265-268.
[9] Walter, M. A., Briel, M., Christ-Crain, M., et al.: Effects of antithyroid drugs on radioiodine treatment: systematic review and meta-analysis of randomised controlled trials. Br. Med. J., 2007, $334(7592), 514$.

[10] Urbannek, V., Voth, E., Moka, D., et al.: Radioiodine therapy of Graves' disease - a dosimetric comparison of various therapy regimens of antithyroid agents. Nuklearmedizin, 2001, 40(4), 111-115.

[11] Bartalena, L., Marcocci, C., Bogazzi, F., et al.: Relation between therapy for hyperthyroidism and Graves' ophthalmopathy. N. Engl. J. Med., 1998, 338(2), 73-78.

[12] Ponto, K. A., Zang, S., Kabaly, G. J.: The tale of radioiodine and Graves' orbitopathy. Thyroid, 2010, 20(7), 785-793.

[13] Träisk, F., Tallstedt, L., Abrabam-Nording, M., et al.: Thyroidassociated ophthalmopathy after treatment for Graves' hyperthyroidism with antithyroid drugs or iodine-131. J. Clin. Endocrinol. Metab., 2009, 94(10), 3700-3707.

[14] Nwatsock, J. F., Taieb, D., Tessonnier, L., et al.: Radioiodine thyroid ablation in Graves' hyperthyroidism: merits and pitfalls. World J. Nucl. Med., 2012, 11(1), 7-11.

[15] Marcocci, C., Altea, M. A., Leo, M.: Treatment options for Graves' orbitopathy. Expert Opin. Pharmacother., 2012, 13(6), 795-806.

[16] Moleti, M., Violi, M. A., Montanini, D., et al.: Radioiodine ablation of postsurgical thyroid remnants after treatment with recombinant human TSH (rhTSH) in patients with moderate-tosevere Graves' orbitopathy (GO): a prospective randomized, single-blind clinical trial. J. Clin. Endocrinol. Metab., 2014, 99(5), 1783-1789.

[17] Stein, J. D., Childers, D., Gupta, S., et al.: Risk factors for developing thyroid-associated ophthalmopathy among individuals with Graves' disease. JAMA Ophthalmol., 2015, 133(3), 290296.

[18] Hegedüs, L., Hansen, B. M., Knudsen, N., et al.: Reduction of size of thyroid with radioactive iodine in multinodular non-toxic goitre. Br. Med. J., 1988, 297(6649), 661-662.

[19] Verelst, J., Bonnyns, M., Glinoer, D.: Radioiodine therapy in voluminous multinodular non-toxic goitre. Acta Endocrinol. (Copenh.), 1990, 122(4), 417-421.

[20] Nygaard, B., Hegediis, L., Gervil, M., et al.: Radioiodine treatment of multinodular non-toxic goitre. Br. Med. J., 1993, 307(6908), 828-832.

[21] Huysmans, D. A, Hermus, A. R., Corstens, F. H., et al.: Large, compressive goiters treated with radioiodine. Ann. Intern. Med., $1994,121(10), 757-762$.

[22] Dietlein, M., Lauterbach, K. W., Schicha, H.: Treatment of toxic nodular goitres: comparative costing of radioiodine therapy and surgery. Exp. Clin. Endocrinol. Diabetes, 1998, 106(Suppl. 4), S66-S70.

[23] Stokkel, M. P., Handkiewicz-Junak, D., Lassmann, M., et al.: EANM procedure giudelines for therapy of benign thyroid disease. Eur. J. Nucl. Med. Mol. Imaging, 2010, 37(11), 22182228.

[24] Eterovic, D., Antunovic, Z., Markovic, V., et al.: Planning of ${ }^{131} \mathrm{I}$ therapy for Graves' disease based on the radiation dose to thyroid follicular cells. J. Nucl. Med., 2008, 49(12), 2026-2030.

[25] De Rooij, A., Vandenbroucke, J. P., Smit, J. W., et al.: Clinical outcomes after estimated versus calculated activity of radioiodine for the treatment of hyperthyroidism: systematic review and metaanalysis. Eur. J. Endocrinol., 2009, 161(5), 771-777.

[26] Bonnema, S. J., Hegediis, L.: Radioiodine therapy in benign thyroid diseases: effects, side effects and factors affecting therapeutic outcome. Endocr. Rev., 2012, 33(6), 920-980.

[27] Emrich, D., Erlenmaier, U., Pobl, M., et al.: Determination of the autonomously functioning volume of the thyroid. Eur. J. Nucl. Med., 1993, 20(5), 410-414.

[28] Reinhardt, M. J., Joe, A., von Mallek, D., et al.: Dose selection for radioiodine therapy of borderline hyperthyroid patients 
with multifocal and disseminated autonomy on the basis of ${ }^{99 \mathrm{~m}}$ Tc-pertechnetate thyroid uptake. Eur. J. Nucl. Med. Mol. Imaging, 2002, 29(4), 480-485.

[29] Reinhardt, M. J., Biermann, K., Wissmeyer, M., et al.: Dose selection for radioiodine therapy of borderline hyperthyroid patients according to thyroid uptake of ${ }^{99 \mathrm{~m}} \mathrm{Tc}$-pertechnetate: applicability to unifocal thyroid autonomy? Eur. J. Nucl. Med. Mol. Imaging, 2006, 33(5), 608-612.

[30] Fast, S., Nielsen, V. E., Bonnema, S. J. et al.: Time to reconsider nonsurgical therapy of benign non-toxic multinodular goitre: focus on recombinant human TSH augmented radioiodine therapy. Eur. J. Endocrinol., 2009, 160(4), 517-528.

[31] Fast, S., Hegedüs, L., Grupe, P., et al.: Recombinant human thyrotropin-stimulated radioiodine therapy of nodular goiter allows major reduction of the radiation burden with retained efficacy. J. Clin. Endocrinol. Metab., 2010, 95(8), 3719-3725.

[32] Kyrilli, A., Tang, B. N., Huyge, V., et al.: Thiamazole pretreatment lowers the ${ }^{131} \mathrm{I}$ activity needed to cure hyperthyroidism in patients with nodular goiter. J. Clin. Endocrinol. Metab., 2015, 100(6), 2261-2267.

[33] Konrády, A.: Immunogenic and non-immunogenic hyperthyroidism: differences and simultaneous occurrence. [Az immunogén és nem immunogén hyperthyreosis különbözősége és együttes előfordulása.] Orv. Hetil., 1984, 125(38), 2317-2320. [Hungarian]

[34] Chiovato, L., Santini, F., Vitti, P., et al.: Appearance of thyroid stimulating antibody and Graves' disease after radioiodine therapy for toxic nodular goitre. Clin. Endocrinol. (Oxf.), 1994, $40(6), 803-806$.

[35] Schmidt, M., Gorbauch, E., Dietlein, M., et al.: Incidence of postradioiodine immunogenic hyperthyroidism/Graves' disease in relation to a temporary increase in thyrotropin receptor antibodies after radioiodine therapy for autonomous thyroid disease. Thyroid, 2006, 16(3), 281-288.

[36] Cooper, D. S., Doherty, G. M., Hangen, B. R., et al.: Revised American Thyroid Association Management Guidelines for patients with thyroid nodules and differentiated thyroid cancer. Thyroid, 2009, 19(11), 1167-1214.

[37] Sacks, W., Wong, R. M., Bresee, C., et al.: Use of evidence-based guidelines reduces radioactive iodine treatment in patients with low-risk differentiated thyroid cancer. Thyroid, 2015, 25(4), 377-385.

[38] Xing, M., Haugen, B. R., Schlumberger, M.: Progress in molecular-based management of differentiated thyroid cancer. Lancet, 2013, 381(9871), 1058-1069.

[39] Ruel, E., Thomas, S., Dinan, M., et al.: Adjuvant radioactive iodine therapy is associated with improved survival for patients with intermediate-risk papillary thyroid cancer. J. Clin. Endocrinol. Metab., 2015, 100(4), 1529-1536.

[40] Barbaro, D., Boni, G., Mencci, G., et al.: Radioiodine treatment with $30 \mathrm{mCi}$ after recombinant human thyrotropin stimulation in thyroid cancer: effectiveness for postsurgical remnants ablation and possible role of iodine content in L-thyroxine in the outcome of ablation. J. Clin. Endocrinol. Metab., 2003, 88(9), $4110-4115$.

[41] Blumbardt, R., Wolin, E. A., Phillips, W. T., et al.: Current controversies in the initial post-surgical radioactive iodine therapy for thyroid cancer: a narrative review. Endocr. Relat. Cancer, 2014, 21(6), R473-R484.

[42] National Comprehensive Cancer Network Clinical Practice Guidelines in Oncology for thyroid carcinoma (version 2.0, 2013). www.nccn.org/professionals/physician

[43] Tuttle, R. M., Ball, D. W., Byrd, D., et al.: Thyroid carcinoma. J. Natl. Compr. Canc. Netw., 2010, 8(11), 1228-1274.

[44] Schlumberger, M., Sherman, S. I.: Approach to the patient with advanced differentiated thyroid cancer. Eur. J. Endocrinol., 2012, 166(1), 5-11.

[45] Franklyn, J. A., Maisonneuwe, P., Sheppard, M.: Cancer incidence and mortality after radioiodine treatment for hyperthyroidism. A population-based cohort study. Lancet, 1999, 353(9170), 2111-2115.

[46] Sawka, A. M., Thabane, L., Parlea, L., et al.: Second primary malignancy risk after radioactive iodine treatment for thyroid cancer: a systematic review and meta-analysis. Thyroid, 2009, 19(5), $451-457$.

[47] Rubino, C., de Vathaire, F., Dottorini, M. E., et al.: Second primary malignancies in thyroid cancer patients. Br. J. Cancer, 2003, 89(9), 1638-1644.

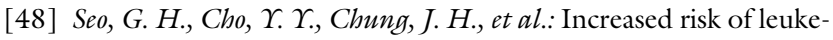
mia after radioactive iodine therapy in patients with thyroid cancer: a nationwide, population-based study in Korea. Thyroid, $2015,25(8), 927-934$.

[49] Chen, A. Y., Levy, L., Goepfert, H., et al.: The development of breast carcinoma in women with thyroid carcinoma. Cancer, 2001, 92(2), 225-231.

[50] La Cour, J. L., Jensen, L. T., Vej-Hansen, A., et al.: Radioiodine therapy increases the risk of cerebrovascular events in hyperthyroid and euthyroid patients. Eur. J. Endocrinol., 2015, 172(6), 771-778.
(Konrády András dr., Budapest, Törökvész út 95-97/C, 1025 e-mail: 2konrady@invitel.hu) 